Research Article

\title{
Identification of Chemical Composition and Metal Determination of Retama raetam (Forssk) Stem Constituents Using ICP-MS, GC-MS-MS, and DART-MS
}

\author{
Wedad Al-Onazi (iD, ${ }^{1}$ Amal M. Al-Mohaimeed $\left(\mathbb{D},{ }^{1}\right.$ Musarat Amina $\left(\mathbb{D},{ }^{2}\right.$ and \\ Maha F. El-Tohamy (iD ${ }^{1}$ \\ ${ }^{1}$ Department of Chemistry, College of Science, King Saud University, Riyadh 11451, Saudi Arabia \\ ${ }^{2}$ Department of Pharmacognosy, College of Pharmacy, King Saud University, Riyadh 11451, Saudi Arabia
}

Correspondence should be addressed to Wedad Al-Onazi; walonazi@ksu.edu.sa and Maha F. El-Tohamy; moraby@ksu.edu.sa

Received 21 November 2020; Revised 7 January 2021; Accepted 13 February 2021; Published 24 February 2021

Academic Editor: Guido Crisponi

Copyright (c) 2021 Wedad Al-Onazi et al. This is an open access article distributed under the Creative Commons Attribution License, which permits unrestricted use, distribution, and reproduction in any medium, provided the original work is properly cited.

\begin{abstract}
This study aims to investigate the chemical constituents of the stem of Retama raetam growing in Saudi Arabia. The organic and inorganic composition of ethanol extract of $R$. raetam stem has been explored using direct analysis in real time-mass spectrometry (DART-MS), gas chromatography-mass spectrometry (GC-MS), and inductively coupled plasma-mass spectrometry (ICP-MS). Analysis conducted by DART-MS and GC-MS reveals the presence of several interesting organic constituents identified as 2,4-di-tert-butylphenol, sparteine, benzenepropanoic acid, 3,5-bis(1,1-dimethylethyl)-4-hydroxy-, methyl ester, phthalic acid, 1-octadecanol, squalene, argentamin, 2,4-di-tert-butylphenol, sparteine, benzene propanoic acid, 3,5-bis(1,1-dimethylethyl)-4-hydroxy-, methyl ester, phthalic acid, 1-octadecanol, squalene, argentamin, and hentriacontane in the ethanol extract of the R. raetam stem. The ICP-MS analysis of stem extract showed the presence of a significant amount of important inorganic elements including aluminum, chlorine, calcium, bromine magnesium, phosphorus, scandium, and chromium. The current study complements other $R$. raetam extract investigations carried out in the past and provides the additional data for the future research studies.
\end{abstract}

\section{Introduction}

Aromatic and medicinal plants are considered as the primary natural source for a wide variety of volatile terpene, hydrocarbons, essential oils, and secondary metabolites. Essential oils also known as volatile oil are being widely used in traditional medicine. Among others, antibacterial, antifungal, antirheumatic, and anti-inflammatory activities have been reported in the literature for these essential oils [1-3]. Genus Retama is comprised of monophyletic taxon belonging to family Fabaceae. It is comprised of four structurally related species distributed from endemic to the Mediterranean area: $R$. sphaerocarpa (L.) Boiss., R. dasycarpa Coss., R. monosperma (L.) Boiss., and R. raetam (Forssk.) Webb $[4,5]$. R. raetam is commonly found in the
Sinai Peninsula and North East Mediterranean region. The extracts of aerial parts of various species of genus Retama are used as traditional remedies in treatment of hypertension, diabetes, rheumatism, and anti-inflammatory diseases [6-8]. Moreover, several studies in the literature report different pharmacological properties of Retama species which includes antioxidant, antibacterial, antifungal, hepatoprotective, antiproliferative, antiulcerogenic, hypoglycemic, antihypertensive, and diuretic effects [9-16]. Phytochemical investigation has shown that Retama species are rich in flavonoids, quinolizidine, and bipiperidyl alkaloids and the cyclitol pinitol compounds [17-21]. Retama raetam (Forssk) Webb, commonly known as ' $\mathrm{R}$ 'tm, is the most valuable aromatic and medicinal wild plant. It is naturally grown in the northeastern Mediterranean region, 
the Sinai Peninsula, Tunisia, Libya, and Saudi Arabia $[22,23]$. The flowers of this plant emit sweet honey aroma, and roots are deeply rooted in the soil. It has slender branches which reduces the exposed surface area to make plants resistant to dry conditions of the desert. The leaves are very small and quickly drop to conserve the water. Traditionally, different parts of plants are used in the treatment of renal and skin diseases. Its extracts are reported to possess potential diuretic activity and could be useful in the cure of hypertension. $R$. raetam have also shown antidiabetic effect. In Tunisia, it is found in abundance and is being used for various industrial purposes. In Algeria and Morocco, it is used to reduce the blood glucose and skin inflammation $[24,25]$. However, in Saudi Arabia, the plant is used for wound healing and inflammation. Also, cattle fed with $R$. raetam made their milk sweeter.

A plenty of scientific data have been generated in the use of traditional medicines in the past two decades mainly encompassing the natural product-based drugs. Hundreds of reports are available in the literature on plant components, their isolation, identification, and studies related to their pharmacological and toxicological properties. Most of the scientific studies of natural products are concerned towards the identification and characterization of organic components, which are mostly secondary metabolites. Indeed, organic compounds are the responsible components of the biological activities. However, the inorganic elements are also present in the plant extracts, and they could play a potential influential role in the therapeutic effects of the natural products. Inorganic components can take part as supplementary materials in addition to the medicinal effects of herbal-based medicines [26, 27].

A number of studies addressed the organic constituents of $R$. raetam; however, the inorganic elements are not reported yet. The current work emphasizes on the organic as well as inorganic components of the $R$. raetam stem extract using DART-MS, GC-MS, and ICP-MS techniques.

\section{Materials and Methods}

2.1. Plant Material. The stems of plant Retama raetam $(2.5 \mathrm{Kg})$ were collected from the Mada'in salehh, North west of Saudi Arabia, in October 2019. The plant material was authenticated and identified by a taxonomist at the Botany Department of King Saud university. The dried stems were coarse powdered in a mixer grinder to get the uniform size. The powdered material of $R$. raetam was transferred to polyethylene plastic polybags and kept in a cold place at $4^{\circ} \mathrm{C}$, until further use.

2.2. DART-MS Analysis. Direct analysis in real-time study was performed in AccuTOF-DART-MS, JEOL (Inc., Peabody, MA, USA), equipped with an ionic source DARTSVPTM (Ionsense, Saugus, MA, USA). Stem sample of the botanical plant material was directly sampled by holding with forceps between the DART ion source and the mass spectrometer. The detection of chemical constituents by this technique does not require the extraction or sample preparation. The volatile components of the stem are evaporated in a stream of helium heated at $350^{\circ} \mathrm{C}$ and were then ionized by excited metastable helium atoms prior to entering the ion source of the mass spectrometer. The molecules are mainly protonated without any fragmentation in a positive ionization mode.

2.2.1. DART-MS Instrumental Parameters. All mass measurements were performed using DART-AccuTOF mass spectrometer in a positive ion mode. Protonated reserpine was used to measure the resolving power of spectrometer at 6000 (FWHM). The mass spectrum of polyethylene glycol (1500 average molecular weight) was chosen as a reference standard for exact mass measurements of each generated compound in the plant sample. The following conditions for the atmospheric pressure interface were applied: ring lens $(4 \mathrm{~V})$; orifice $1(10 \mathrm{~V})$ and orifice $2(5 \mathrm{~V})$. The voltage of radio frequency (RF) ion guide was adjusted at $800 \mathrm{~V}$ to permit detection of ions greater than $m / z 80$. Helium gas was used as a DART ion source at the $350^{\circ} \mathrm{C}$ with a flow rate $2 \mathrm{~L} / \mathrm{min}$ and a grid voltage of $530 \mathrm{~V}$, and input gas pressure was adjusted to $1.8 \times 10^{-2} \mathrm{~Pa}$ (Airgas, Cambridge, MA). Elemental compositions of chemical constituents detected were compared with accurate mass spectral data with well-developed library of plant components isolated from the NIST standard reference database (2008 database).

\subsection{Preparation of $R$. raetam Extract for GC-MS Analysis.} To analyze the organic components $R$. raetam plant, powdered stem (100 g) was subjected to ethanol extraction. The plant powder was soaked in $300 \mathrm{~mL}$ of ethanol for $48 \mathrm{~h}$, at ambient temperature. The ethanolic extract was drained, filtered, centrifuged, and freed from solvent on the rotavapour at $\pm 50^{\circ} \mathrm{C}$, under reduced pressure to get the dark brown residue $(16.5 \mathrm{~g})$. The obtained extract was stored in the refrigerator at $4^{\circ} \mathrm{C}$ in dark air-tight bottles prior to further analysis with GC-MS.

2.3.1. GC-MS Instrumental Conditions. The chemical composition of the ethanol extract obtained from the stem of $R$. raetam was analyzed in a Thermo Trace GC ultra-gas chromatography coupled with a TSQ quantum mass spectrometer (triple quadrupole), available at College of Science, King Saud University. $2 \mu \mathrm{l}$ solution of stem extract of $R$. raetam was loaded into the glass capillary column fused with Elite-5MS column $(30 \times 0.25 \mathrm{~mm}$ internal diameter with $0.25 \mathrm{~mm} \times 0.25 \mu \mathrm{m}$ film thickness). The stationary phase is $5 \%$ phenyl polysilphenylene-siloxane. The temperature of the oven was set at $40^{\circ} \mathrm{C}, 5 \mathrm{~min}$, reaching $300^{\circ} \mathrm{C}$ at an acceleration rate of $10^{\circ} \mathrm{C} / \mathrm{min}$. The injector and detector temperature was maintained at $250^{\circ} \mathrm{C}$. Helium was used as the carrier gas with a flow rate of $0.5 \mathrm{~mL}$ and a split flow of $25 \mathrm{~mL} / \mathrm{min}$, corresponding to split ratio of 50 . The total acquisition time for analysis was $75 \mathrm{~min}$. Mass detector scanning was carried out at 40 to $500(\mathrm{~m} / \mathrm{z})$, in an ionization mode. The mass detector was operated at $70 \mathrm{eV}$ ionization energy and $0.132 \mathrm{~s} / \mathrm{scan}$ in the full scan mode. Relative 
abundance (\% area) calculations were based on the ratio between the peak area of each compound and the sum of the peak areas of all compounds [28]. National Institute of Standard and Technology (v2.1, NIST, 2005, Wiley) library was used to identify the unknown components and the comparison with literature reported.

\subsection{Preparation of Sample for ICP-MS Analysis by Microwave} Digestion. The dried, powdered plant material $(515 \mathrm{mg})$ was placed in dry, clean Teflon microwave digestion vessel, to which $2.0 \mathrm{~mL}$ of concentrated $\mathrm{HNO}_{3}, 6.0 \mathrm{~mL}$ of $\mathrm{HCl}$, and $2.0 \mathrm{~mL}$ of HF were added. The sample was then subjected to digestion using scientific microwave (Model Milestone Ethos 1600 ) at $165^{\circ} \mathrm{C}$ for $10 \mathrm{~min}$ with the microwave irradiation of $1000 \mathrm{~W}$ power, followed by a dwell time $20 \mathrm{~min}$ at $165^{\circ} \mathrm{C}$. The temperature and pressure limit was $175^{\circ} \mathrm{C}$ and 15.2 bar (220 psi), respectively. After cooling, the resulting digest was transferred to a $50 \mathrm{~mL}$ plastic volumetric flask and made up to the mark using deionized water. A blank digest was carried out in the same way.

2.4.1. ICP-MS Instrumental Conditions. For the trace elemental analysis of $R$. raetam, the instrument NexION 300D (inductively coupled plasma-mass spectrometer, PerkinElmer, USA) was used to conduct the ICP-MS analysis. Table 1 highlights the operating conditions of the instruments used in this study.

\subsubsection{Calibration of ICP-MS and Internal Standard.} Instrument calibration was performed using $1.0 \mathrm{ppb}$ multielement internal standard solution in $1 \%$ nitric acid of various elements such as lithium $\left({ }^{6} \mathrm{Li}\right)$, beryllium $\left({ }^{9} \mathrm{Be}\right)$, zinc $\left({ }^{67} \mathrm{Zn}\right)$, selenium $\left({ }^{78} \mathrm{Se}\right)$, bromine $\left({ }^{81} \mathrm{Br}\right)$, cobalt $\left({ }^{59} \mathrm{Co}\right)$, sodium $\left({ }^{23} \mathrm{Na}\right)$, magnesium $\left({ }^{24} \mathrm{Mg}\right)$, silicon $\left({ }^{28} \mathrm{Si}\right)$, iron $\left({ }^{57} \mathrm{Fe}\right)$, chromium $\left({ }^{53} \mathrm{Cr}\right)$, lead $\left({ }^{208} \mathrm{~Pb}\right)$, copper $\left({ }^{63} \mathrm{Cu}\right)$, copper $\left({ }^{65} \mathrm{Cu}\right)$, and barium $\left({ }^{136} \mathrm{Ba}\right)$. The same standard solution was applied to optimize the gas flow, mass calibration, resolution, and AutoLens calibration. For all analyses, $20 \mathrm{ppb}$ multielement internal standard solution was used.

2.5. Bacterial Strains. Five different pathogenic bacterial strains were used in this study including Salmonella typhi ATCC, Escherichia coli ATCC, Pseudomonas aeruginosa ATCC, and Klebsiella pneumoniae ATCC as Gram-negative and Staphylococcus aureus ATCC as Gram-positive bacterial strain. The bacterial strains were supplied by the King Khalid Hospital, Saudi Arabia, and were used to investigate the antibacterial potential of ethanol extract of $R$. raetam. Various physiological, morphological, and biochemical tests were conducted to identify the selected bacterial strains [29]. All bacterial isolates were tested for antibacterial susceptibility by modifying the Kirby-Bauer disc diffusion method following the Clinical and Laboratory Standards Institute (CLSI) guidelines [30].

2.6. Antibacterial Assay of R. raetam Extract. Agar well diffusion method was used to investigate the antibacterial potential of ethanol extract of $R$. raetam stem in
TABLE 1: Instrument operating conditions for the determination of metallic species in $R$. raetam.

\begin{tabular}{lc}
\hline \multicolumn{2}{c}{ Instrument operating conditions } \\
\hline R power & $1600 \mathrm{~W}$ \\
Nebulizer gas flow & $0.92 \mathrm{~L} / \mathrm{min}$ \\
Lens voltage & $9.25 \mathrm{~V}$ \\
Analog stage voltage & $-1762.5 \mathrm{~V}$ \\
Pulse stage voltage & $1050 \mathrm{~V}$ \\
Number of replicates & 3 \\
Reading/replicates & 20 \\
Scan mode & Peak hopping \\
Dwell time & $40 \mathrm{~ms}$ \\
Integration & $1200 \mathrm{~ms}$ \\
\hline
\end{tabular}

Mueller-Hinton Agar (MHA) plates [31]. The test bacterial strains were placed in nutrient broth and incubated for $12 \mathrm{~h}$ at $37^{\circ} \mathrm{C}$ to make the turbidity to $0.5 \mathrm{McF}$ arland standards yielding a final inoculum of $1.5 \times 108 \mathrm{CFU} / \mathrm{mL}$. The standardized bacterial culture was spread on MHA plate. $50 \mathrm{mg} \cdot \mathrm{mL}^{-1}$ solution of plant extract was prepared in dimethyl sulfoxide (DMSO). A sterile cork-borer was used to bore the inoculated media into the wells, and $50 \mu \mathrm{L}$ of plant extract was added to each well. Streptomycin was used as positive control, while DMSO was used as a negative control. The mixture was allowed to diffuse for approximately $30 \mathrm{~min}$ at ambient temperature and incubated at $37^{\circ} \mathrm{C}$ for one complete day. After the incubation time, the plates were evaluated for clear zone formation around the well, which expresses the antibacterial potential of the tested plant extract. The zone of inhibition was measured in $\mathrm{mm}$.

2.7. Determination of MIC of the Plant Extract. MIC was determined by using a broth microdilution procedure according to the instruction of CLSI. Microorganisms were cultured in nutrient broth for $6 \mathrm{~h} .20 \mathrm{~mL}$ of the cultured bacterial strains were inoculated in the tubes containing nutrient broth supplemented with seven different concentrations $(20,40,80,160,320,640$, and $1280 \mathrm{~mL})$ of the plant extract $\left(25 \mathrm{mg} \mathrm{mL}^{-1}\right)$ and incubated for one day at $37^{\circ} \mathrm{C}$. The MIC of the sample was determined by measuring the optical density using spectrophotometer at $620 \mathrm{~nm}$. Chloramphenicol was used as a standard substance [32].

2.8. DPPH Free Radical Scavenging Activity. The antioxidant effect of $R$. raetam stem extract was determined spectrophotometrically using the DPPH method by modifying previously described Brand-Williams et al. [33]. The method was conducted by mixing $1.5 \mathrm{~mL}$ of $20 \mu \mathrm{g} \mathrm{mL}^{-1}$ of DPPH solution with $0.75 \mathrm{~mL}$ of $100 \mu \mathrm{g} \mathrm{mL}^{-1}$ of plant extract. The sample under investigation was mixed well and kept in a dark at ambient temperature for $30 \mathrm{~min}$. The absorbance of the mixture was measured spectrophotometrically at $517 \mathrm{~nm}$ against blank solution $(0.75 \mathrm{~mL}$ of water mixed with $1.5 \mathrm{~mL}$ $\mathrm{DPPH}$ ) using UV-Vis spectrophotometer (Shimadzu, Kyoto, Japan). Furthermore, to eliminate the crude extract absorbance, a blank sample was prepared by mixing $0.75 \mathrm{~mL}$ of plant extract with $1.5 \mathrm{~mL}$ of methanol. Thus, the 
antioxidant capacity percentage was calculated using the following equation:

$$
\text { antioxidant activity }(\%)=\left[\frac{\left(A_{\text {Control }}-A_{\text {Extract }}\right)}{A_{\text {Control }}}\right] \times 100,
$$

where $A_{\text {Control }}$ and $A_{\text {Extract }}$ are the absorbance of the DPPH solution without the extract and absorbance of the tested plant extract with DPPH, respectively.

\section{Results and Discussion}

3.1. Chemical Analysis of R. raetam Stem Extract by DART$M S, G C-M S$, and ICP-MS. In the current study, phytochemical evaluation of organic and inorganic components of $R$. raetam stem extract were identified and quantitatively estimated by DART-MS, GC-MS, and ICP-MS analysis. A significant quantity of 22 organic chemical components was determined using DART-MS technique (Table 2). Figure 1 displays the mass spectrum of organic compounds by the DART-MS, whereas 12 organic constituents were estimated by GC-MS technique (Table 3). Figure 2 illustrates the chromatogram of organic compounds of $R$. raetam stem extract by GC-MS. However, a total of 33 inorganic constituents were detected using ICP-MS technique (Table 4). The results revealed that a significant amount of important organic compounds identified in the $R$. raetam stem extract include adiponitrile, 2-isopropylimidazole, cinachyrazole C, cadalene, 8-hexylisoquinoline, sparteine, 2-dodecyl-1Himidazole, and 4-methyl-2-undecylimidazole in DART-MS analysis. Also, the GC-MS results showed the presence of valuable organic constituents, including 2,4-di-tert-butylphenol, sparteine, benzene propanoic acid, 3,5-bis $(1,1-$ dimethylethyl)-4-hydroxy-, methyl ester, phthalic acid, 1octadecanol, squalene, argentamin, and hentriacontane

Sparteine is a heterobicyclononane alkaloid known to possess antiarrhythmic effect, to decrease the incidences of ventricular tachycardia and fibrillation, and helps in reduction of blood pressure and heart rate $[34,35]$. It also showed a hypoglycemic effect and induces glucagon and insulin secretions in the pancreas [36, 37]. Other biological properties which are reported for this alkaloid include antiinflammatory, antibacterial, and diuretic effects and induce uterine contractions [38, 39].

GC-MS analysis estimated and identified the presence of hentriacontane in the stem extract of $R$. raetam (Table 3 ). Hentriacontane is reported to possess anti-inflammatory effects on the lipopolysaccharide- (LPS-) induced inflammatory responses in mouse peritoneal macrophages. It has inhibited the production of interleukin (IL-6), tumor necrosis factor (TNF- $\alpha$ ), and prostaglandin-E2 (PGE 2), suggesting a potential candidate for the development of new inflammatory drugs to cure inflammatory diseases [40].

Antibacterial, antifungal, and cytotoxicity activities of R. raetam extract has been reported in the literature [10], which revealed that the constituents present in the plant have a major role in biological properties. A study conducted on a flower extract of $R$. raetam showed strong antimicrobial activity against $P$. aeruginosa, E. coli, and Candida species (7.81-15.62 $\left.\mu \mathrm{g} \mathrm{mL}^{-1}\right)$. The tested plant extract as well as flavonoids isolated showed strong cytotoxicity against Hep2 cells [10].

Hentriacontane also known as untriacontane is a long chain hydrocarbon belonging to organic class alkanes. It is commonly found in a variety of food items such as saffron, sweet cherry coconut, and swamp cabbage. This makes a potential biomarker for the consumption of these food products. It has been reported for various pharmacological properties including, antitumor, anti-inflammatory, and antimicrobial activities [41].

Reactive oxygen species (ROS) are known to be responsible for oxidative cellular macromolecules damages such as nucleic acids, lipids, and proteins. These types of biological destruction may lead to disease progression and cell death. The stem extract of $R$. raetam displayed potent DPPH radical scavenging activity. The results attributed this activity due to the presence of terpenoids and flavonoids in the plant extract [42]. All of these addressed features of the $R$. raetam could be taken into account to support its medicinal applications in a traditional folk system of medicine [43]. In the current work, appreciable amount of sesquiterpenoids was detected in the $R$. raetam stem extract.

Inorganic components play a vital role in the survival of the bioactive chemical entities. In addition to four basis building elements hydrogen, carbon, oxygen, and nitrogen (forming main organic molecules), various inorganic components are required by the living organisms for their healthy survival. Several elements are essentially required for normal physiological body functions in humans [44]. In the current analysis, a total of 33 inorganic elements were detected in the $R$. raetam stem extract (Table 4), suggesting that they have an important role in biological functions in mankind.

The concentration of calcium was found to be the highest in the sample followed by iron, potassium, and sodium. Calcium is a vital element for numerous physiological functions and a structural material for bone in combination with phosphorus. Intake of calcium supplement helps in preventing bone fracture and calcium deficiency disorders [45]. Calcium was determined in the highest amount (71951 $\pm 3.1 \mathrm{mg} \mathrm{Kg}^{-1}$ ) among all the inorganic elements identified in the tested plant in the present study. Other potential nutrient elements found in the extract were iron, potassium, and sodium (Table 4). Iron is an important element which helps in oxygen carrying capacity of hemoglobin. It is also found in various important enzymes such as cytochrome p450 enzyme. The amount of iron recorded in R. raetam stem extract was $1054.487 \pm 1.0 \mathrm{mg} \mathrm{Kg}^{-1}$ (Table 4).

Potassium, which was also found in higher quantity in the $R$. raetam extract $\left(15267.514 \pm 0.9 \mathrm{mg} \mathrm{Kg}^{-1}\right)$, is reported to participate in regulating fluid balance, nerve signals, and muscle contraction. Studies have shown that high-potassium diet helps in reducing blood pressure and water retention, prevent osteoporosis and kidney stones, and protect against stroke.

Sodium is one of the useful elements required in small amounts via food to perform the normal biological 
TABLE 2: The main constituents characterized in $R$. raetam plant stem by DART-MS.

\begin{tabular}{|c|c|c|c|c|c|c|}
\hline S. no. & $\begin{array}{l}\text { Experimental } \\
\text { mass }\end{array}$ & $\begin{array}{l}\text { Calculated } \\
\text { mass }\end{array}$ & $\begin{array}{c}\text { Mass } \\
\text { difference } \\
(\mathrm{mmu})\end{array}$ & Formula & Proposed name & Unsaturation degree \\
\hline 1 & 108.06872 & 108.06875 & -0.03 & $\mathrm{C}_{6} \mathrm{H}_{8} \mathrm{~N}_{2}$ & Adiponitrile & 4.0 \\
\hline 2 & 110.08439 & 110.08440 & 0.00 & $\mathrm{C}_{6} \mathrm{H}_{10} \mathrm{~N}_{2}$ & 2-Isopropylimidazole & 3.0 \\
\hline 3 & 168.12352 & 168.12626 & -2.74 & $\mathrm{C}_{9} \mathrm{H}_{16} \mathrm{~N}_{2} \mathrm{O}$ & $\begin{array}{l}\text { 3-(1-Ethyl-1-methylpropyl)-5- } \\
\text { isoxazolamine }\end{array}$ & 3.0 \\
\hline 4 & 169.12916 & 169.12962 & -0.45 & $\mathrm{C}_{8}{ }^{13} \mathrm{CH}_{16} \mathrm{~N}_{2} \mathrm{O}$ & Unknown & 3.0 \\
\hline 5 & 195.12322 & 195.12459 & -1.36 & $\mathrm{C}_{9} \mathrm{H}_{14} \mathrm{~N}_{4} \mathrm{O}$ & Cinachyrazole C & 4.5 \\
\hline 6 & 196.12730 & 196.12794 & -0.64 & $\mathrm{C}_{8}{ }^{13} \mathrm{CH}_{15} \mathrm{~N}_{4} \mathrm{O}$ & Unknown & 4.5 \\
\hline 7 & 212.14524 & 212.14392 & 1.31 & $\mathrm{C}_{15} \mathrm{H}_{18} \mathrm{~N}$ & Cadalene & 7.5 \\
\hline 8 & 213.15411 & 213.15175 & 2.36 & $\mathrm{C}_{15} \mathrm{H}_{19} \mathrm{~N}$ & 8-Hexylisoquinoline & 7.0 \\
\hline 9 & 232.19781 & 232.19395 & 3.86 & $\mathrm{C}_{15} \mathrm{H}_{24} \mathrm{~N}_{2}$ & 1,5-Dicyclohexylimidazole & 5.0 \\
\hline 10 & 233.20650 & 233.20177 & 4.73 & $\mathrm{C}_{15} \mathrm{H}_{25} \mathrm{~N}_{2}$ & Unknown & 4.5 \\
\hline 11 & 234.21224 & 234.20960 & 2.64 & $\mathrm{C}_{15} \mathrm{H}_{26} \mathrm{~N}_{2}$ & Sparteine & 4.0 \\
\hline 12 & 235.21931 & 235.21742 & 1.89 & $\mathrm{C}_{15} \mathrm{H}_{27} \mathrm{~N}_{2}$ & 4-Methyl-2-undecylimidazole & 3.5 \\
\hline 13 & 236.22711 & 236.22525 & 1.87 & $\mathrm{C}_{15} \mathrm{H}_{28} \mathrm{~N}_{2}$ & 2-Dodecyl-1H-imidazole & 3.0 \\
\hline 14 & 237.22944 & 237.22860 & 0.83 & $\mathrm{C}_{14}{ }^{13} \mathrm{CH}_{28} \mathrm{~N}_{2}$ & Unknown & 3.0 \\
\hline 15 & 239.15370 & 239.15482 & -1.12 & $\mathrm{C}_{16} \mathrm{H}_{19} \mathrm{~N}_{2}$ & $\begin{array}{l}\text { 4-(4-Dimethylaminostyryl)-1- } \\
\text { methylpyridinium }\end{array}$ & 8.5 \\
\hline 16 & 240.15655 & 240.15818 & -1.63 & $\mathrm{C}_{15}{ }^{13} \mathrm{CH}_{19} \mathrm{~N}_{2}$ & Unknown & 8.5 \\
\hline 17 & 247.18814 & 247.18959 & -1.45 & $\mathrm{C}_{11} \mathrm{H}_{25} \mathrm{~N}_{3} \mathrm{O}_{3}$ & $\begin{array}{l}\text { 2-Amino- } N, N \text {-diethylpropanamide; } \\
\text { methyl }(2 S) \text {-2-aminopropanoate }\end{array}$ & 1.0 \\
\hline 18 & 248.19482 & 248.19295 & 1.87 & $\mathrm{C}_{10}{ }^{13} \mathrm{CH}_{25} \mathrm{~N}_{3} \mathrm{O}_{3}$ & Unknown & 1.0 \\
\hline 19 & 249.20279 & 249.20524 & -2.45 & $\mathrm{C}_{11} \mathrm{H}_{27} \mathrm{~N}_{3} \mathrm{O}_{3}$ & $\begin{array}{c}N^{\prime} \text {-[2-(4,4,4-Trimethoxybutylamino) } \\
\text { ethyl]ethane-1,2-diamine }\end{array}$ & 0.0 \\
\hline 20 & 250.20532 & 250.20860 & -3.27 & $\mathrm{C}_{10}{ }^{13} \mathrm{CH}_{27} \mathrm{~N}_{3} \mathrm{O}_{3}$ & Unknown & 0.0 \\
\hline 21 & 256.17922 & 256.18137 & -2.15 & $\mathrm{C}_{16} \mathrm{H}_{22} \mathrm{~N}_{3}$ & $\begin{array}{l}\text { 2-(3-Propylbenzimidazol-3-ium-1-yl) } \\
\text { hexanenitrile }\end{array}$ & 7.5 \\
\hline 22 & 257.18411 & 257.18473 & -0.62 & $\mathrm{C}_{15}{ }^{13} \mathrm{CH}_{22} \mathrm{~N}_{3}$ & Unknown & 7.5 \\
\hline
\end{tabular}

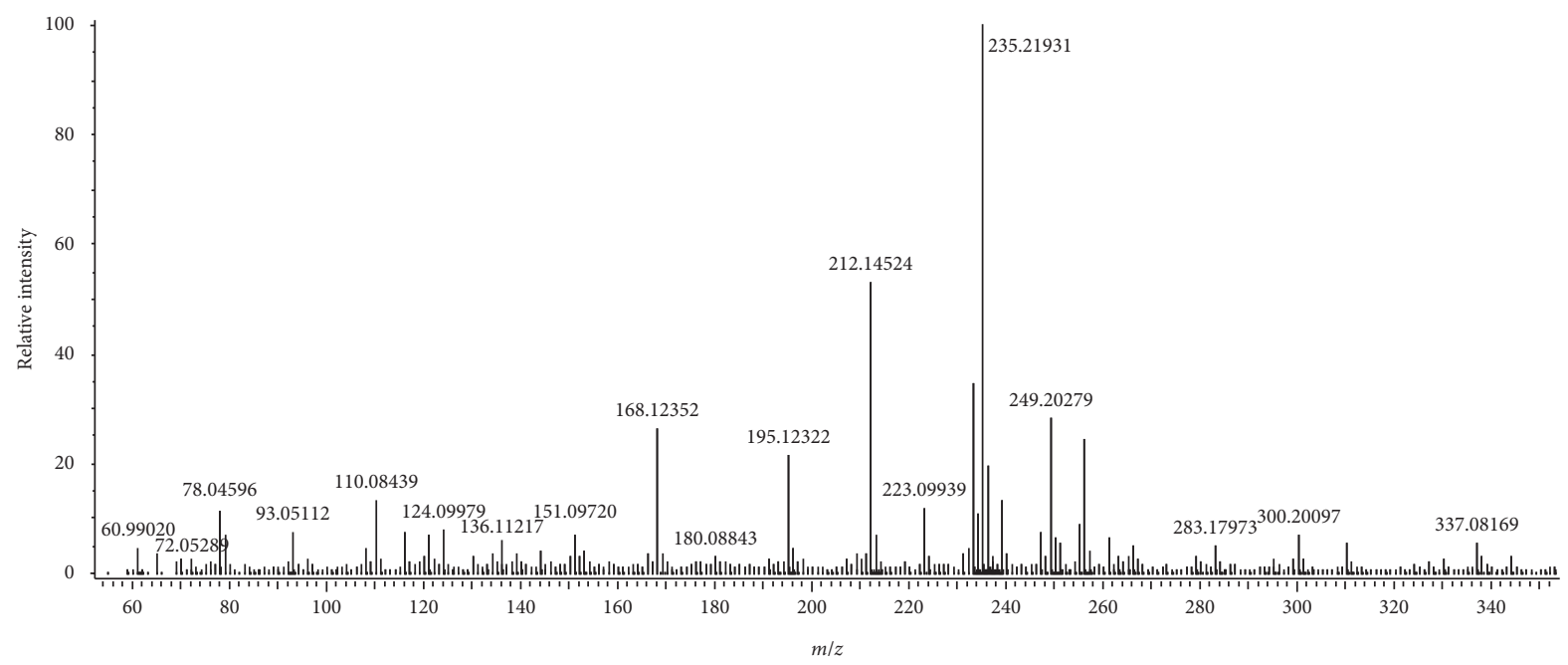

FIGURE 1: Main constituents characterized in R. raetam plant stem by DART-MS.

processes. It helps to conduct nerve impulses, maintain the proper balance of water and minerals, and contraction and relaxation of muscles. The daily requirement of sodium by the human body is $500 \mathrm{mg}$. In the current investigation, $531.674 \pm 2.4 \mathrm{mg} \mathrm{Kg}^{-1}$ of sodium was detected in the R. raetam extract. Higher levels of sodium intake have been negatively correlated with the risk of high blood pressure, heart disease, and stroke. Other significant trace nutrient elements detected in the $R$. raetam extract were phosphorus, strontium, manganese, and chromium (Table 4). Phosphorus is considered as an important component of bones, teeth, DNA, and RNA. It plays a crucial role in the structure of cell membrane and a key source of body's energy. Several sugars and proteins present in the body are phosphorylated. In this study, phosphorus has been found in an appreciable amount $\left(701.293 \pm 2.1 \mathrm{mg} \mathrm{Kg}^{-1}\right)$.

The results of the current investigation revealed that four elements other than essential ones caught the attention for 
TABle 3: Constituents identified in $R$. raetam plant stem extract by GC-MS.

\begin{tabular}{|c|c|c|c|c|c|c|}
\hline S. no. & Proposed compound & Formula & M.W. & $\begin{array}{c}\mathrm{Rt} \\
(\mathrm{min} .)\end{array}$ & $\begin{array}{l}\text { Area } \\
(\%)\end{array}$ & Composition (\%) \\
\hline 1 & 2,4-di-tert-butylphenol & $\mathrm{C}_{14} \mathrm{H}_{22} \mathrm{O}$ & 206 & 19.68 & 0.820 & 14.584 \\
\hline 2 & Sparteine & $\mathrm{C}_{15} \mathrm{H}_{26} \mathrm{~N}_{2}$ & 234 & 25.93 & 3.232 & 7.84 \\
\hline 3 & $\begin{array}{c}\text { Benzenepropanoic acid, 3,5-bis(1,1-dimethylethyl)-4-hydroxy-, } \\
\text { methyl ester }\end{array}$ & $\mathrm{C}_{18} \mathrm{H}_{28} \mathrm{O}_{3}$ & 292 & 28.70 & 13.460 & 4.47 \\
\hline 4 & Phthalic acid, butyl nonyl ester & $\mathrm{C}_{21} \mathrm{H}_{32} \mathrm{O}_{4}$ & 348 & 29.35 & 4.280 & 6.89 \\
\hline 5 & 1-Octadecanol & $\mathrm{C}_{18} \mathrm{H}_{38} \mathrm{O}$ & 270 & 31.62 & 2.340 & 4.13 \\
\hline 6 & 5,6-Dehydrolupanine & $\mathrm{C}_{15} \mathrm{H}_{22} \mathrm{~N}_{2} \mathrm{O}$ & 246 & 34.05 & 2.321 & 8.74 \\
\hline 7 & Diisooctyl phthalate & $\mathrm{C}_{24} \mathrm{H}_{38} \mathrm{O}_{4}$ & 390 & 39.28 & 36.420 & 2.13 \\
\hline 8 & 1,3-Benzenedicarboxylic acid, bis(2-ethylhexyl)ester & $\mathrm{C}_{24} \mathrm{H}_{38} \mathrm{O}_{4}$ & 390 & 42.38 & 4.262 & 10.54 \\
\hline 9 & Squalene & $\mathrm{C}_{30} \mathrm{H}_{50}$ & 410 & 43.16 & 28.210 & 8.91 \\
\hline 10 & Argentamin & $\mathrm{C}_{15} \mathrm{H}_{20} \mathrm{~N}_{2} \mathrm{O}_{2}$ & 260 & 43.92 & 1.252 & 5.20 \\
\hline 11 & Hentriacontane & $\mathrm{C}_{31} \mathrm{H}_{64}$ & 436 & 47.08 & 0.962 & 24.71 \\
\hline 12 & Methyl 8,14-epoxy-15-hydroxy-16-nor-pimarate & $\mathrm{C}_{20} \mathrm{H}_{32} \mathrm{O}_{4}$ & 336 & 49.59 & 1.587 & 1.56 \\
\hline
\end{tabular}

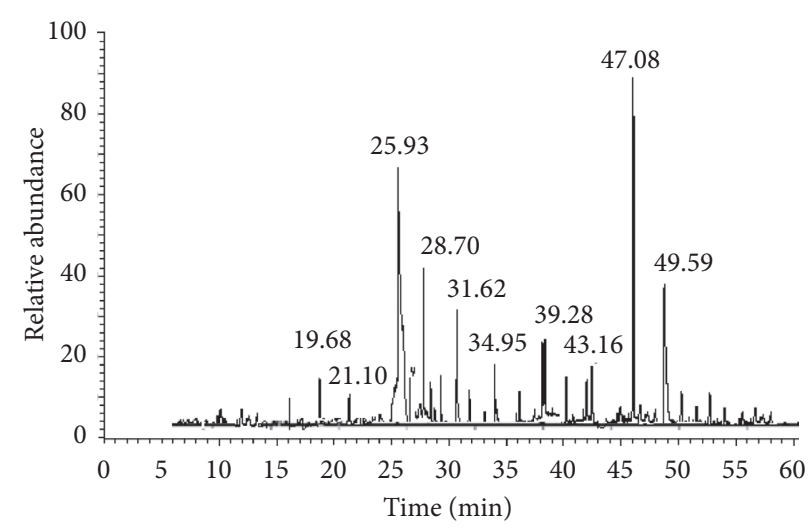

Figure 2: GC-MS-MS chromatogram of ethanol stem extract of R. raetam.

TABLE 4: Elements and heavy metals concentration R. raetam stem $\left(\mathrm{mgKg}^{-1}\right)$.

\begin{tabular}{|c|c|c|c|c|c|}
\hline Element & Amount $\left(\mathrm{mg} \mathrm{Kg}^{-1}\right)$ & Element & Amount $\left(\mathrm{mg} \mathrm{Kg}^{-1}\right)$ & Element & Amount $\left(\mathrm{mg} \mathrm{Kg}^{-1}\right)$ \\
\hline $\mathrm{Li}$ & $1.213 \pm 1.6$ & $\mathrm{Mn}$ & $108.878 \pm 2.7$ & $\mathrm{Ag}$ & $0.307 \pm 2.4$ \\
\hline $\mathrm{Na}$ & $531.674 \pm 2.4$ & $\mathrm{Fe}$ & $1054.487 \pm 1.0$ & $\mathrm{Cd}$ & $0.124 \pm 3.0$ \\
\hline B & $157.829 \pm 2.4$ & Co & $0.813 \pm 1.1$ & Sn & $1.005 \pm 1.8$ \\
\hline $\mathrm{Mg}$ & $7387.130 \pm 1.0$ & $\mathrm{Ni}$ & $4.508 \pm 1.1$ & $\mathrm{Sb}$ & $0.1083 .1 \pm 1.4$ \\
\hline $\mathrm{Al}$ & $409.554 \pm 1.1$ & $\mathrm{Cu}$ & $6.648 \pm 0.7$ & $\mathrm{Ba}$ & $15.622 \pm 1.0$ \\
\hline $\mathrm{Si}$ & $1122.7 \pm 3.0$ & $\mathrm{Zn}$ & $17.495 \pm 2.1$ & $\mathrm{La}$ & $0.456 \pm 2.5$ \\
\hline $\mathrm{P}$ & $701.293 \pm 2.1$ & As & $1.400 \pm 2.4$ & $\mathrm{Ce}$ & $0.851 \pm 0.5$ \\
\hline $\mathrm{K}$ & $15267.514 \pm 0.9$ & $\mathrm{Br}$ & $35.389 \pm 0.9$ & $\mathrm{~W}$ & $0.550 \pm 0.7$ \\
\hline $\mathrm{Ca}$ & $71951 \pm 3.1$ & $\mathrm{Sr}$ & $361.079 \pm 2.8$ & $\mathrm{Hg}$ & $0.299 \pm 1.0$ \\
\hline $\mathrm{Ti}$ & $14.276 \pm 2.4$ & Mo & $1.049 \pm 0.7$ & $\mathrm{~Pb}$ & $0.960 \pm 0.6$ \\
\hline $\mathrm{Cr}$ & $50.962 \pm 1.9$ & $\mathrm{Pd}$ & $0.279 \pm 1.6$ & $\mathrm{Bi}$ & $0.406 \pm 2.2$ \\
\hline
\end{tabular}

their substantial quantity in the $R$. raetam stem extract. These include bromine $(35.389 \pm 0.9)$, barium $\left(15.622 \pm 1.0 \mathrm{mg} \mathrm{Kg}^{-1}\right)$, copper $\left(6.648 \pm 0.7 \mathrm{mg} \mathrm{Kg}^{-1}\right)$, and arsenic $\left(1.400 \pm 2.4 \mathrm{mg} \mathrm{Kg}^{-1}\right)$. These inorganic elements are toxic in nature. Table 3 also demonstrates the other elements identified in trace amounts.

3.2. Evaluation of Antibacterial Potential of R. raetam Stem Extract. Antibacterial activity of $R$. raetam stem extract was determined using agar well diffusion method against five different bacterial strains. The plant extract used in this study showed a varying degree of antibacterial potential against all the bacterial strains used. The potency of plant extract was measured qualitatively as well as quantitatively to access the presence or absence of zone of inhibition, zone diameter, and MIC values. Streptomycin and DMSO were used as positive and negative control, respectively. The data presented in Table 5 show that the ethanol extract of $R$. raetam stem has excellent antibacterial activity against all tested bacterial strains. The results revealed that the highest zone of inhibition was recorded against $P$. aeruginosa $(6.2 \mathrm{~mm})$ and 
TABLE 5: Antimicrobial activities of $R$. raetam plant extract measured by agar well diffusion and MIC methods.

\begin{tabular}{lcccc}
\hline Test microorganisms & Plant extract $(\mathrm{mm})$ & Control $(\mathrm{mm})$ & Plant extract MIC $(\mathrm{mm})$ & Control MIC $(\mathrm{mm})$ \\
\hline Salmonella typhi & 3.5 & 1.3 & 1.6 & 6.0 \\
Escherichia coli & 3.8 & 2.8 & 9.3 & 10.0 \\
Pseudomonas aeruginosa & 6.2 & 1.7 & 2.0 & 6.5 \\
Klebsiella pneumoniae & 4.2 & 2.6 & 9.2 & 10.3 \\
Staphylococcus aureus & 5.8 & 3.7 & 5.0 & 10.5 \\
\hline
\end{tabular}

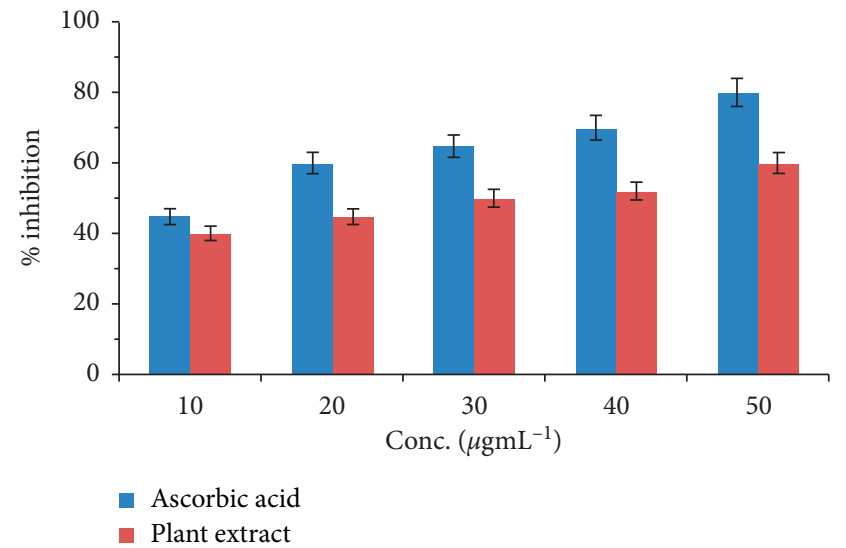

FIGURE 3: Results of DPPH radical scavenging potential of the $R$. raetam stem in comparison with ascorbic acid as reference.

S. aureus $(5.8 \mathrm{~mm})$, whereas the streptomycin gave inhibition zone between 1.65 and $3.74 \mathrm{~mm}$. The ethanol extract of $R$. raetam showed a MIC of 2 and $5 \mathrm{mg} \mathrm{mL}^{-1}$ against $P$. aeruginosa and $S$. aureus, respectively. However, chloramphenicol had varied MIC from 6.5 to $10.5 \mathrm{mg} \mathrm{mL}^{-1}$. The results obtained in the present study supports with the previous study conducted by Awen et al. (2011) [46].

3.3. Evaluation of Antioxidant Potential of R. raetam Stem Extract. The antioxidant potential of $R$. raetam stem extract was evaluated using DPPH free radical scavenging assay. It is considered as one of the simplest, effective, reliable, reactive, and reproducible in vitro procedures used for the evaluation of pure compound's activity as well as a plant extract. The results of DPPH radical scavenging potential of the $R$. raetam stem was compared with reference (ascorbic acid) and are presented in Figure 3. The measured antioxidant potential was estimated as $\mathrm{IC}_{50}$ values of $\mathrm{DPPH}$ free radical scavenging activity exhibiting strong antioxidant activity for the ethanol extract of $R$. raetam stem. The $\mathrm{IC}_{50}$ values obtained were 32.6 and $12.8 \mu \mathrm{g} \mathrm{mL}^{-1}$ for the extract and ascorbic acid, respectively. The free radical scavenging abilities of the ethanol plant extract were lower as compared to ascorbic acid. The obtained results indicated that $R$. raetam stem extract has a strong hydrogen-donating ability, can act as a free radical scavenger, and can serve as possible substitute primary antioxidant. The strong antioxidant potential of $R$. raetam stem extract can be attributed to the presence of secondary metabolites.

\section{Conclusion}

This study provides an insight about the bioactive organic metabolites as well as beneficial inorganic elements of ethanol extract of $R$. raetam stem. It is probably the first report regarding the inorganic elements of the $R$. raetam extract and clearly supports the traditional use of $R$. raetam in the folk, traditional system of medicine. As a whole, $R$. raetam extract contains essential inorganic components needed for biological functions and traces of mercury, arsenic, and lead toxic elements. The outcome of present investigation offers the excellent role of the inorganic constituents in the medicinal properties together with its organic components. It also indicated the possibility of using this plant as a source of supplements for various inorganic elements in case of deficiency.

\section{Data Availability}

All the data included are present within the text.

\section{Conflicts of Interest}

The authors declare that they have no conflicts of interest.

\section{Acknowledgments}

This research project was supported by a grant from the Research Center of the Female Scientific and Medical Colleges, Deanship of Scientific Research, King Saud University, Riyadh, Saudi Arabia.

\section{References}

[1] S. Nam, H. W. Jang, and T. Shibamoto, “Antioxidant activities of extracts from teas prepared from medicinal plants, morus alba L., camellia sinensis L., and cudrania tricuspidata, and their volatile components," Journal of Agricultural and Food Chemistry, vol. 60, no. 36, pp. 9097-9105, 2012.

[2] H. W. Kim, S. Y. Choi, H. S. Jang, B. Ryu, S. H. Sung, and H. Yang, "Exploring novel secondary metabolites from natural products using pre-processed mass spectral data," Scientific Reports, vol. 9, p. 1, 2019.

[3] A. K. Shakya, "Medicinal plants: future source of new drugs," International Journal of Herbal Medicine, vol. 4, pp. 59-64, 2016.

[4] B. Zoubir and K. H. Meriem, "Evaluation of genetic diversity in three species of Retama genus: R. monosperma (L) Boiss, R. raetam (Forssk) Webb and R. sphaerocarpa (L) 
Boiss.(Fabaceae) based on SDS-PAGE," Current Research Journal of Biological Sciences, vol. 4, pp. 202-205, 2012.

[5] W. Greuter, H. M. Burdet, and G. Long, A Critical Inventory of Vascular Plants of the Circum-Mediterranean Countries, p. 4, Dicotyledones (Lauraceae-Rhamnaceae), Geneva, Switzerland, 1989.

[6] K. Rebbas, R. Bounar, R. Gharzouli, M. Ramdani, Y. Djellouli, and D. Alatou, "Plantes d'intérêt médicinale et écologique dans la région d'Ouanougha (M'sila, Algérie)," Phytothérapie, vol. 10, no. 2, pp. 131-142, 2012.

[7] A. Nelly, D. D. Annick, and D. Frederic, "Plants used as remedies antirheumatic and antineuralgic in the traditional medicine of Lebanon," Journal of Ethnopharmacology, vol. 120, pp. 315-334, 2008.

[8] A. Tahraoui, J. El-Hilaly, Z. H. Israili, and B. Lyoussi, "Ethnopharmacological survey of plants used in the traditional treatment of hypertension and diabetes in south-eastern Morocco (Errachidia province)," Journal of Ethnopharmacology, vol. 110, no. 1, pp. 105-117, 2007.

[9] E. Hayet, M. Maha, A. Samia et al., "Antimicrobial, antioxidant, and antiviral activities of Retama raetam (Forssk.) Webb flowers growing in Tunisia," World Journal of Microbiology and Biotechnology, vol. 24, no. 12, pp. 2933-2940, 2008.

[10] H. Edziri, M. Mastouri, M. A. Mahjoub, Z. Mighri, A. Mahjoub, and L. Verschaeve, "Antibacterial, antifungal and cytotoxic activities of two flavonoids from Retama raetam flowers," Molecules, vol. 17, no. 6, pp. 7284-7293, 2012.

[11] S. El-Toumy, A. Farrag, M. Ellithey, and K. Korien, "Effect of plant derived-phenolic extracts on antioxidant enzyme activity and mucosal damage caused by indomethacin in rats," Planta Medica, vol. 75, no. 09, p. PH11, 2009.

[12] P. Bremner, D. Rivera, M. A. Calzado et al., "Assessing medicinal plants from South-Eastern Spain for potential antiinflammatory effects targeting nuclear factor-Kappa B and other pro-inflammatory mediators," Journal of Ethnopharmacology, vol. 124, no. 2, pp. 295-305, 2009.

[13] H. González-Mauraza, C. Martín-Cordero, C. Alarcón-de-laLastra, M. A. Rosillo, A. J. León-González, and M. SánchezHidalgo, "Anti-inflammatory effects of Retama monosperma in acute ulcerative colitis in rats," Journal of Physiology and Biochemistry, vol. 70, no. 1, pp. 163-172, 2014.

[14] M. M. Algandaby, H. A. Alghamdi, O. M. Ashour et al., "Mechanisms of the antihyperglycemic activity of Retama raetam in streptozotocin-induced diabetic rats," Food and Chemical Toxicology, vol. 48, no. 8-9, pp. 2448-2453, 2010.

[15] M. Eddouks, M. Maghrani, L. Louedec, M. Haloui, and J. B. Michel, "Antihypertensive activity of the aqueous extract of retama raetam forssk. Leaves in spontaneously hypertensive rats," Journal Of Herbal Pharmacotherapy, vol. 7, no. 2, pp. 65-77, 2008.

[16] M. Maghrani, N.-A. Zeggwagh, M. Haloui, and M. Eddouks, "Acute diuretic effect of aqueous extract of Retama raetam in normal rats," Journal of Ethnopharmacology, vol. 99, no. 1, pp. 31-35, 2005.

[17] M. López-Lázaro, C. Martín-Cordero, and M. Ayuso, "Flavonoids ofRetama sphaerocarpa," Planta Medica, vol. 65, no. 8, pp. 777-778, 1999.

[18] M. E. Kassem, S. A. Mosharrafa, N. A. Saleh, and S. A. Wahab, "Flavonoids of retama raetam, and in vitro antitumor screening of two isoflavones, Egypt," Journal of Pharmaceutical Sciences, vol. 47, p. 1, 2006.

[19] A. El-Shazly, A.-M. Ateya, L. Witte, and M. Wink, "Quinolizidine alkaloid profiles of Retama raetam, R. sphaerocarpa and R. monosperma," Zeitschrift für Naturforschung C, vol. 51, no. 5-6, pp. 301-308, 1996.

[20] F. Sandberg, "The alkaloids of Retama raetam Webb \& berth," Pharmaceutisch Weekblad, vol. 93, p. 8, 1958.

[21] N. H. González-Mauraza, A. J. León-González, J. L. Espartero, J. B. Gallego-Fernández, M. Sánchez-Hidalgo, and C. MartinCordero, "Isolation and quantification of pinitol, a bioactive cyclitol, in retama spp," Natural Product Communications, vol. 11, no. 3, Article ID 1934578X1601100, 2016.

[22] L. El Bahri, M. Djegham, and H. Bellil, "Retama raetam W: a poisonous plant of North Africa," Veterinary and Human Toxicology, vol. 41, p. 33, 1999.

[23] R. Mittler, E. Merquiol, E. Hallak-Herr, S. Rachmilevitch, A. Kaplan, and M. Cohen, "Living under a 'dormant' canopy: a molecular acclimation mechanism of the desert plant Retama raetam," The Plant Journal, vol. 25, no. 4, pp. 407-416, 2001.

[24] S. Archer and D. A. Pyke, "Plant-animal interactions affecting plant establishment and persistence on revegetated rangeland," Journal of Range Management, vol. 44, no. 6, pp. 558-565, 1991.

[25] I. Izhaki and G. Ne'eman, "Hares (Lepusspp.) as seed dispersers ofRetama raetam(Fabaceae) in a sandy landscape," Journal of Arid Environments, vol. 37, no. 2, pp. 343-354, 1997.

[26] S. R. Ahamad, A. R. Al-Ghadeer, R. Ali, W. Qamar, and S. Aljarboa, "Analysis of inorganic and organic constituents of myrrh resin by GC-MS and ICP-MS: an emphasis on medicinal assets," Saudi Pharmaceutical Journal, vol. 25, no. 5, pp. 788-794, 2017.

[27] M. Frankowski, "Simultaneous determination of inorganic and organic ions in plant parts of Betula pendula from two different types of ecosystems (Wielkopolski National Park and Chemical Plant in Luboń, Poland)," Environmental Science and Pollution Research, vol. 23, no. 11, pp. 11046-11057, 2016.

[28] D. Topi, "Volatile and chemical compositions of freshly squeezed sweet lime (Citrus limetta) juices," Journal of Raw Materials to Processed Foods, vol. 1, pp. 22-27, 2020.

[29] T. Hussain, A. Roohi, S. Munir et al., "Biochemical characterization and identification of bacterial strains isolated from drinking water sources of Kohat, Pakistan," African Journal of Microbiology Research, vol. 7, pp. 1579-1590, 2013.

[30] J. J. Biemer, "Antimicrobial susceptibility testing by the KirbyBauer disc diffusion method, Annals Clin," Clinical Laboratory Science, vol. 3, pp. 135-140, 1973.

[31] P.-C. Trinh, L.-T.-T. Thao, H.-T.-V. Ha, and T. Nguyen, "DPPH-scavenging and antimicrobial activities of Asteraceae medicinal plants on uropathogenic bacteria," Evidence-Based Complementary and Alternative Medicine, vol. 2020, Article ID 7807026, 9 pages, 2020.

[32] P. Charles, A. Kali, and S. Srirangaraj, "Comparison of carbapenem breakpoints in clinical laboratory standard Institute and European committee on antimicrobial susceptibility testing guidelines on antibiotic susceptibility test reporting of acinetobacter baumannii," Indian Journal of Pathology \& Microbiology, vol. 59, p. 429, 2016.

[33] W. Brand-Williams, M. E. Cuvelier, and C. Berset, "Use of a free radical method to evaluate antioxidant activity," LWT Food Science and Technology, vol. 28, no. 1, pp. 25-30, 1995.

[34] J. Senges and L. Ehe, "Antiarrhythmic action of sparteine on direct and indirect models of cardiac fibrillation," NaunynSchmiedeberg's Archives of Pharmacology, vol. 280, no. 3, pp. 265-274, 1973. 
[35] P. Gremigni, J. Hamblin, and D. Harris, "Genotypex environment interactions and lupin alkaloids. InLupin, an ancient crop for the new millennium," in Proceedings of the 9th International Lupin Conference, pp. 362-365, International Lupin Association, Klink/Müritz, Germany, June 2000.

[36] G. Paolisso, M. Nenquin, W. Schmeer, F. Mathot, H. P. Meissner, and J. C. Henquin, "Sparteine increases insulin release by decreasing the $\mathrm{K}+$ permeability of the B-cell membrane," Biochemical Pharmacology, vol. 34, no. 13, pp. 2355-2361, 1985.

[37] S. Sgambato, G. Paolisso, N. Passariello, M. Varricchio, and F. D'Onofrio, "Effect of sparteine sulphate upon basal and nutrient-induced insulin and glucagon secretion in normal man," European Journal of Clinical Pharmacology, vol. 32, no. 5, pp. 477-480, 1987.

[38] T. Schmeller and M. Wink, "Utilization of alkaloids in modern medicine," pp. 435-459, Springer, Boston, MA, 1998.

[39] R. De la Vega, M. P. Gutierrez, C. Sanz et al., "Bactericide-like effect of Lupinus alkaloids," Industrial Crops and Products, vol. 5, no. 2, pp. 141-148, 1996.

[40] S.-J. Kim, W.-S. Chung, S.-S. Kim, S.-G. Ko, and J.-Y. Um, "Antiinflammatory effect of oldenlandia diffusa and its constituent, hentriacontane, through suppression of caspase-1 activation in mouse peritoneal macrophages," Phytotherapy Research, vol. 25, no. 10, pp. 1537-1546, 2011.

[41] V. Khajuria, S. Gupta, N. Sharma et al., "Anti-inflammatory potential of hentriacontane in LPS stimulated RAW 264.7 cells and mice model," Biomedicine \& Pharmacotherapy, vol. 92, pp. 175-186, 2017.

[42] M. Nur-e-Alam, M. Yousaf, I. Parveen et al., "New flavonoids from the Saudi Arabian plant Retama raetam which stimulates secretion of insulin and inhibits $\alpha$-glucosidase," Organic \& Biomolecular Chemistry, vol. 17, no. 5, pp. 1266-1276, 2019.

[43] H. Edziri, M. Mastouri, I. Chéraif, and M. Aouni, "Chemical composition and antibacterial, antifungal and antioxidant activities of the flower oil ofRetama raetam(Forssk.) Webb from Tunisia," Natural Product Research, vol. 24, no. 9, pp. 789-796, 2010.

[44] G. Colotti, A. Ilari, A. Boffi, and V. Morea, "Metals and metal derivatives in medicine," Mini-Reviews in Medicinal Chemistry, vol. 13, no. 2, pp. 211-221, 2013.

[45] D. C. Bauer, "Calcium supplements and fracture prevention," New England Journal of Medicine, vol. 369, no. 16, pp. 1537-1543, 2013.

[46] B. Z. S. Awen, C. R. Unnithan, S. Ravi et al., "Essential oils ofRetama raetamfrom Libya: chemical composition and antimicrobial activity," Natural Product Research, vol. 25, no. 9, pp. 927-933, 2011. 